\title{
Assessing sport brand value through use of the contingent valuation method
}

\author{
J. Lucy Lee ${ }^{a^{*}}$, Jeffrey D. James ${ }^{b}$ \\ a Assistant Professor, Sport Management Program, Bowling Green State University, United States. \\ b Department of Sport Management, Florida State University, United States. \\ *Corresponding author's email address: jielee@bgsu.edu
}

\section{A R T I C L E I N F O}

Received: 30-09-2015

Accepted: 12-11-2015

Available online: 19-11-2015

\section{Keywords:}

Brand equity measurements; Contingent valuation method (CVM);

Sport brand value.

JEL Classification: G32; D63; Q21; P42; C83.

\begin{abstract}
A B S T R A C T
This work is a first attempt to estimate customer-based brand equity with the contingent valuation method (CVM) for a service-oriented product. We assess the value of a sport brand, IRONMAN triathlon, utilizing the CVM - one of the few available measures for estimating intangible product values. The equity of the IRONMAN brand was derived from consumers' perceptions, attitudes, and behaviours by asking consumers (i.e., triathletes who have experiences with IRONMAN and non-IRONMAN branded events) about their willingness to pay for an IRONMAN and generic non-IRONMAN triathlon events. We found (1) the presence of price premiums that sport consumers were willing to pay for the branded sport product and (2) the estimated brand equity value of approximately \$102 million for IRONMAN Half-distance events, and \$123 million for IRONMAN Full-distance event.
\end{abstract}

(C) 2015 The Authors. This is an open access article under the terms of the Creative Commons Attribution License 4.0, which allows use, distribution and reproduction in any medium, provided the original work is properly cited.

DOI: http://dx.doi.org/10.18533/jefs.v3i6.179

\subsection{Introduction}

The concept of brand equity is widely recognized in academic theory and in commercial practice (Aaker, 1991; 1996; de Chernatony, Harris, \& Christodoulide, 2004; Keller, 1993; 2001; 2008; Simon \& Sullivan, 1993). There is agreement on the general concept: the added value of a particular brand accrues beyond the utilitarian or functional value of a product. However, measurement of brand equity is not well established. A critical challenge in analyzing brand equity is, thus, identifying intangible elements that comprise a consumer's evaluation of brand equity. One problem is that previous research has provided evidence only of the existence of brand equity. In practice, such limited information does not allow for comparison of the brand equity of market competitors. Furthermore, although researchers have attempted to provide a numerical value for brand equity through financial market measures, these data are too limited to be valid and sufficient when applied to, for example, the sports industry. Because access to organizational data, including financial data, is restricted in this particular industry, it is difficult to accurately assess brand equity using financial market measures. Other previous measures (e.g., customer mindset, product outcome) do not provide numeric values; they only verify the components of brand equity (Buil, de Chernatony, \& Martinez, 2008; Lassar, Mittal, \& Sharma, 1995; Vázquez, del Rio, \& Iglesias, 2002; Yoo \& Donthu, 2001) and the magnitude of an individual's willingness to pay a price premium (include references). Thus, we propose an approach that provides an economic dollar value from the consumer's perspective by using the contingent valuation method (CVM). 
In this paper, we hypothesize that there exists a difference between a customer's willingness to pay for a branded event compared with a corresponding unbranded event, which is a price premium. Based on the price premium that an individual places on the brand, we estimate the customer-based brand equity of a sporting event. The first research question is crucial because the result represents whether consumers place additional monetary value on an event (i.e., price premium). Once we discern if there is indeed a willingness to pay premium prices on an event, we can proceed with regards to how much it is and how it will be as a whole to estimate brand equity from customers' perspectives.

In order to measure customer-based brand equity utilizing CVM, customer survey estimation on non-pecuniary products, we collect data at sporting events - the IRONMAN triathlon in particular. Adult triathletes who have experienced both non-branded and branded events participated in the survey. The price premium is computed by ANOVA, and brand equity of the IRONMAN triathlon is estimated based on the price premiums.

Attempts to assess the value/equity of a branded sports product through the CVM from the perspective of sports customers are a unique research endeavor. The results will provide multiple contributions, including (a) a strong selling point for building and developing relationships with business partners; (b) an indicator when setting a strategic pricing policy; and (c) a good information source for a business to examine its current status by comparing its value with competitors' values. Although we focus on sport products, the potential to measure brand equity may be applied to any type of branded product.

The article proceeds as follows. In the next section, we discuss the concept of brand equity and its measurements and the CVM. In the following section, we examine whether there is a price premium for sports consumers on either branded or unbranded triathlon events. In the final section, we identify practical insights and strategies that sport executives and practitioners can apply by utilizing CVM to measure customer-based brand equity in participant sports.

\subsection{Literature and hypothesis development}

While there is no one single definition for brand equity, scholars acknowledge that the concept has been approached from both firm-based and customer-based perspectives. A firm-based approach (Ambler, 2003; Farquhar, 1989; Simon \& Sullivan, 1993) relies more on future financial returns, due to the brand-name effect. The customer-based approach (Keller, 1993) focuses on the customer's psychology and perceptions. Table 1 includes definitions based on each approach. Regardless of approach, the concept can be understood as the incremental value that a brand name generates for a firm and/or a consumer over a period of time.

\begin{tabular}{|c|c|c|}
\hline \multicolumn{3}{|c|}{ Table 01: Definitions of brand equity } \\
\hline Scholar & Perspective & Definitions \\
\hline Farquhar (1989) & Firm-based & $\begin{array}{l}\text { "the added value to the firm, the trade, or the consumer with } \\
\text { which a given brand endows a product" (p. } 32 \text { ). }\end{array}$ \\
\hline $\begin{array}{l}\text { Simon \& Sullivan } \\
(1993)\end{array}$ & Firm-based & $\begin{array}{l}\text { "the incremental cash flows which accrue to branded products } \\
\text { over unbranded products" (p. 28). }\end{array}$ \\
\hline Ambler (2003) & Firm-based & $\begin{array}{l}\text { "the accumulated intangible asset from past marketing that has } \\
\text { not yet been taken into profit" (p. 47). }\end{array}$ \\
\hline Aaker (1991) & Customer-based & $\begin{array}{l}\text { "a set of assets (and liabilities) linked to a brand's name and } \\
\text { symbol that adds to (or subtracts from) the value provided by a } \\
\text { product or service to a firm and/or that firm's customers" (pp. } \\
\text { 7-8). }\end{array}$ \\
\hline Keller (1993) & Customer-based & $\begin{array}{l}\text { "the differential effect of brand knowledge on consumer } \\
\text { response to the marketing of the brand" (p. 8). }\end{array}$ \\
\hline
\end{tabular}

\subsection{Brand equity: Measurement}

Because there is, in general, no universally accepted tool for assessing brand equity, researchers and practitioners have attempted to develop and utilize various methods to estimate brand value, which can be classified into three categories as proposed by Keller and Lehmann (2006): (1) customer mindset measures; (2) financial market measures; and (3) product market measures.

Customer mindset measures are based on the premise that several sources represent brand equity. That is, customers' thoughts, feelings (e.g., brand image), evaluations (e.g., brand attitude), and behaviors (e.g., brand loyalty) are elements of brand equity. Aaker's 1991 and Keller's (1993; 2001; 2008) conceptual frameworks significantly influenced customer mindset measures. Later researchers employed components of their models 
either implicitly or explicitly (Agarwal \& Rao, 1996; Buil, de Chernatony, \& Martinez, 2008; Lassar, Mittal, \& Sharma, 1995; Vázquez, del Rio, \& Iglesias, 2002; Yoo \& Donthu, 2001, Gladden, Milne, \& Sutton, 1998; Mackay, 2001; Ross, 2006).

Because many studies were based on Aaker's and Keller's frameworks, the driving forces of brand equity were theoretically sound and supported. However, questions remained whether equity was truly being measured. Brand equity measures were essentially a combination of statistically identified components (e.g., brand awareness, brand image, brand loyalty). Previous studies of purporting to address brand equity measurement (Buil, de Chernatony, \& Martinez, 2008; Gladden, Irwin \& Sutton, 2001; Lassar, Mittal, \& Sharma, 1995; Vázquez, del Rio, \& Iglesias, 2002; Yoo \& Donthu, 2001) have been focused on advancing our understanding of the components of brand equity, not necessarily the measurement of brand equity per se. It is not clear, however, the manner in which the components believed to comprise brand equity should be brought together to provide a single value of brand equity. In contrast with customer mindset measures, financial market measures may provide a specific numerical dollar value for brand equity.

Financial-market measures of brand equity are derived from a firm's financial information—assets, liabilities, and cash flows on financial statements. An accurate brand equity value would be obtained when the firm is sold or acquired and the value based on the firm's financial statements (Farquhar, 1990; Feldwick, 1996; Mahajan, Rao, \& Srivastava, 1994). Financial market measures take into account the net discounted cash flow derived from a brand and the potential future growth of a brand.

If appropriately used and if sufficient and valid financial data were available, the financial market measures can be the most accurate method for evaluating a firm's performance. In the sports industry, however, the accessibility of organizational data is limited. It is difficult to claim research on sports brand equity using financial market measures to provide an accurate brand value for sports entities (see Boone, Kochunny, \& Wilkins, 1995; Gladden \& Milne, 1999). In addition, the financial measures do not provide any factors or components showing the expansion of market shares and generation of profits due to brand recognition. Kapferer (2004) once advised that researchers should be cautious when applying financial market measures. Without valid and sufficient data to analyze, evaluating brand equity via financial market measures would be inaccurate.

The most commonly used measure for reflecting brand equity in product market outcome measures is identification of the price premium. One common format is directly asking consumers about their willingness to pay top dollar for branded products (Faircloth, Capella, \& Alford, 2001; Park \& Srinivasan, 1994). It also could be examined by a form of conjoint analysis (Krishinan \& Hartline, 2001), thus drawing a conclusion based on a consumer's choice between two options. Product market outcome measures are beneficial in that their values reflect the accumulated perceptions and evaluations of a customer regarding the focal brand through various mechanisms. It would offer the financial valuation derived from several potential components of brand equity in a customer's cognition process.

Product market outcome measures, however, have drawbacks. Consumers may have confused a firm's brand positioning strategies (e.g., low-valued price) with a lower level of brand equity. For example, Wal-Mart has a high level of brand equity despite its low-valued price tactics. In this case, consumers may indicate that they would pay lower premiums because the current prices influenced and confused their perceptions of brand equity. In other words, low-price brands would not necessarily mean those companies had lower brand equity.

In the current study, we apply the CVM based on the price premium, thus consumer's willingness to pay top dollar on the product. The method has been widely applied in economics and sport economics in an attempt to capture the nonmonetary value of a focal product. The CVM enables us to obtain an individual respondent's willingness to pay (i.e., a baseline for evaluating the event or entry fees) for both a branded product and an unbranded product. The difference between willingness to pay for the branded and unbranded products is the price premium. Product market outcome research (i.e., price premium research) and the CVM estimate an individual's willingness to pay the price premium. However, unlike in most previous price premium research, in regards to whether there exists price premium or the magnitude of premiums, we figure an actual dollar value of the price premium.

Many researchers have reported the existence of a premium price on the branded product. As consumers perceive higher product quality merits, where characteristics, features, or an assessment of the relevant attributes compared to other relevant competitors' brands determines quality, they more likely pay additional dollar (Holbrook 1992; Peterson \& Wilson, 1985; Shapiro, 1983). Further, as the magnitude of differentiation and uniqueness relative to competitors increases, consumers' willingness to pay premium prices increases as well (Anselmsson et al., 2007, Netemeyer et al., 2004; Sethuraman, 2001). Sethuraman and Cole (1999) emphasize that, because of the possible risk that a consumer may experience after performance or financial failure, 
consumers are willing to pay premiums to avoid the perceived risk associated with the product (Ailawadi, Lehmann, \& Neslin, 2003). In general, consumers pay the excess price for multiple reasons, and, regardless of reasons, they justify doing so by understanding the price as the fair and true value of product. Accordingly, we propose the following hypothesis.

Hypothesis 1: There a difference between a customer's willingness to pay for a branded event compared with a corresponding unbranded event.

\subsection{Contingent Valuation Method (CVM)}

The CVM has been widely used in environmental economics. Policymakers in various organizations and researchers in academe have used the CVM as a tool for estimating nonuse resources (Blomquist \& Whitehead, 1998; Cummings, Brookshire, Schulze, \& Bishop, \& Arrow, 1986; Klose, 1999). The method was applied in the contexts of estimating the costs of natural resources (Rulleau, Dehez, \& Point, 2012) in tropical developing countries (Shyamsundar \& Kramer, 1996); improving and purifying water (Carson \& Mitchell, 1993); and health services (Ryan \& Watson, 2009). Provided in Table 2 is a summary of key studies utilizing CVM.

Table 2: A summary of representative studies utilizing contingent valuation method

\begin{tabular}{|c|c|c|c|}
\hline \multicolumn{2}{|c|}{ Categories } & Author(s) & Applications \\
\hline \multirow[t]{6}{*}{$\begin{array}{l}\text { Non- } \\
\text { sport }\end{array}$} & \multirow[t]{4}{*}{$\begin{array}{l}\text { Natural } \\
\text { resource }\end{array}$} & Rulleau, Dehez, \& Point (2012) & $\begin{array}{l}\text { To estimate the recreational quality of a site } \\
\text { between tourists and residents }\end{array}$ \\
\hline & & Whitehead \& Cherry (2007) & $\begin{array}{l}\text { To assess the annual benefits of the regional } \\
\text { amenities associated with a Green Energy } \\
\text { program }\end{array}$ \\
\hline & & $\begin{array}{l}\text { Shyamsundar \& Kramer } \\
\text { (1996) }\end{array}$ & $\begin{array}{l}\text { To examine the value of tropical forest } \\
\text { resources for a rural population }\end{array}$ \\
\hline & & Carson \& Mitchell (1993) & $\begin{array}{l}\text { To identify the value of improving and } \\
\text { purifying water }\end{array}$ \\
\hline & \multirow[t]{2}{*}{$\begin{array}{l}\text { Health } \\
\text { services }\end{array}$} & Ryan \& Watson (2009) & $\begin{array}{l}\text { To discover women's preferences for } \\
\text { Chlamydia screening }\end{array}$ \\
\hline & & Clarke (2001) & $\begin{array}{l}\text { To identify improving access to } \\
\text { mammographic screening in rural areas }\end{array}$ \\
\hline \multirow[t]{14}{*}{ Sport } & \multirow[t]{4}{*}{ Mega events } & $\begin{array}{l}\text { Atkinson, Mourato, Szymanski, } \\
\text { \& Ozdemiroglu (2008) }\end{array}$ & $\begin{array}{l}\text { To test intangible impacts to justify hosting the } \\
2012 \text { Summer Olympic Games }\end{array}$ \\
\hline & & Sussmuth, Heyne, \& Maenning & To assess the value of hosting a first FIFA \\
\hline & & $(2010)$ & World Cup finals hosted by reunified Germany \\
\hline & & $\begin{array}{l}\text { Walton, Longo, \& Dawson } \\
\text { (2008) }\end{array}$ & $\begin{array}{l}\text { To estimate the value of the } 2012 \text { London } \\
\text { Olympic Games }\end{array}$ \\
\hline & \multirow[t]{3}{*}{$\begin{array}{l}\text { Professional } \\
\text { sports }\end{array}$} & $\begin{array}{l}\text { Johnson, Groothuis, \& } \\
\text { Whitehead (2001) }\end{array}$ & $\begin{array}{l}\text { To measure the value of public goods } \\
\text { generated by a professional sports team, the } \\
\text { Pittsburgh Penguins of the National Hockey } \\
\text { League }\end{array}$ \\
\hline & & Johnson, Mondello, \& & To test he value of public goods \\
\hline & & Whitehead (2007) & $\begin{array}{l}\text { the National Football League's Jaguars } \\
\text { produce for Jacksonville, Florida }\end{array}$ \\
\hline & \multirow[t]{2}{*}{$\begin{array}{l}\text { Amateur } \\
\text { sports }\end{array}$} & $\begin{array}{l}\text { Johnson, Whitehead, Mason, \& } \\
\text { Walker (2007) }\end{array}$ & $\begin{array}{l}\text { To examine the enhancements in the } \\
\text { province's extensive sport and recreation } \\
\text { programs }\end{array}$ \\
\hline & & Wicker (2011) & $\begin{array}{l}\text { To analyze members' willingness-to pay } \\
\text { (WTP) for membership fees }\end{array}$ \\
\hline & $\begin{array}{l}\text { Recreational } \\
\text { nature sport } \\
\text { site }\end{array}$ & Rollins \& Wistowksy, (1997) & $\begin{array}{l}\text { To estimate the value of back-country } \\
\text { canoeing in Ontario provincial wilderness } \\
\text { parks }\end{array}$ \\
\hline & $\begin{array}{l}\text { National } \\
\text { sporting }\end{array}$ & Rätzel \& Weimann, (2006) & $\begin{array}{l}\text { To measure the social welfare which will be } \\
\text { produced by the German National Soccer }\end{array}$ \\
\hline & successes & & Team during the World Cup 2006. \\
\hline & & Wicker et al. (2012) & To measure the value of Olympic success \\
\hline & Ticket prices & Drayer \& Shapiro (2011) & $\begin{array}{l}\text { To examine the value that consumers placed } \\
\text { on a ticket to a National Basketball Association } \\
\text { game }\end{array}$ \\
\hline
\end{tabular}


Johnson and Whitehead (2000) first proposed used the method for estimating an individual's willingness to pay more taxes for supporting the construction of a new sports stadium with governmental subsidies. Since that work, the CVM has been applied over the past two decades in sports finance and sports economics. Several sport economists have emphasized the importance of the intangible benefits that sporting events, stadium, and professional sports franchises generate (e.g., Coates \& Humphreys, 1999, 2000; Crompton, 1995). Crompton (2004) once defined intangible benefits as "psychic income." The CVM has been applied in an attempt to quantify these intangible benefits.

According to Wicker et al. (2012), studies utilizing the CVM can be classified into five main subjects: (1) mega events (Atkinson, Mourato, Szymanski, \& Ozdemiroglu 2008); (2) professional sports (Johnson, Groothuis, \& Whitehead 2001); (3) amateur sports (Johnson, Whitehead, Mason, \& Walker 2007); (4) recreational nature sport sites (Rulleau et al., 2012); and (5) national sporting successes (Wicker et al., 2012). The method was also used in creating ticket prices (Drayer \& Shapiro 2011), a category added to a classification of Wicker et al. (2012). Walker and Mondello (2007) once noted that, because the CVM has many applications and provides researchers and economists with insight, it represents an important component of economic valuation. However, several methodological limitations exist due to attempting to quantify an immeasurable value (see Table 2).

Methodological limitations of the CVM include the discrepancy between an actual price and an individual's willingness to pay for the focal product (i.e., hypothetical bias); the different outcomes of willingness-to-pay-based and willingness-to-accept-based measures (i.e., endowment effect); the predisposed results from too much involvement in a research project or from expressing an individual's protest against the research product (i.e., strategic bias); the skewed outcomes because of cognitive difficulties or a lack of knowledge of a focal product (i.e., information bias); and the presence of a biased willingness to pay due to the order of items in a questionnaire or the measurement unit/level of a research object (i.e., embedding bias).

Despite the limitations, it is important to note that the CVM is essentially one of the few available techniques for measuring the tangibility and intangibility of non-pecuniary assets. That is why the panelists of the NOAA recommended the CVM for future research (Arrow, Solow, Portney, Leamer, Radner, \& Schuman, 1993). We applied the CVM to measure brand equity while controlling the biases through particular methodological buffers, including research design, survey methods truth-telling inclusion, statistical analysis, and detailed explanations of the research object.

In order to gain additional information and represent a particular brand equity value, we propose using the CVM to measure brand equity. In addition, the CVM enables researchers to obtain the aggregate economic value from the customers' perspectives that previous price premium researchers did not offer. Main differences distinguish the current study, thus utilizing the CVM from other price premium research. Hence, we propose:

Research Question 1: What is the customer-based brand equity of a sporting event based on the price premium that an individual places on the brand?

\subsection{Data and methodology}

The research objects for the current study were an IRONMAN triathlon event and a non-IRONMAN triathlon event. We selected to examine the specific case of the IRONMAN triathlon brand for three reasons. First, the total number of triathlon participants has grown. An estimated 798,000 participated in 2007; that figure has nearly doubled in five years: 1,686,000 triathletes competing in 2012. As the number of participants increases, their collective purchasing power also increases. The triathlon is one of the fastest-growing segments of the recreation sports market (Courey, 2013). Second, the IRONMAN triathlon organization also has been rapidly expanding its markets to Europe, Asia, and South America based on the triathlon's popularity. By 2013, the IRONMAN triathlon organization was operating 180 IRONMAN events in 20 countries, spread over virtually every continent (Courey, 2013). Third, the IRONMAN triathlon is replacing all similar events for running, biking, and swimming and becoming a representative brand for those triathlon events. This is supported by ticket prices and the time all tickets sell out compared with other triathlons.

\subsection{Data collection}

Data were collected from individuals participating in the IRONMAN event held in Panama City Beach, Florida (November, 2013), and Oceanside, California (March, 2014). We contacted a specialist at the Global Branding Creative Services in the World Triathlon Corporation (i.e., the organization that runs IRONMAN triathlon events) via e-mail to ask permission to access participants at the IRONMAN triathlon events. Data were collected face-toface two to three days prior to the race day - the preferred time to freely contact triathletes when they preregister for next year's event, pick up the triathlon race packets, and browse triathlon equipment at the IRONMAN village. 
Participants voluntarily participated in an approximately 12 minute paper and pencil questionnaire. We screened the respondents depending on their previous experience in both IRONMAN and non-IRONMAN-branded triathlon events. The respondents for the current study (i.e., triathletes) should have experiences with IRONMAN and nonIRONMAN triathlon events.

The respondents for the current study were adult triathletes. To evaluate the accuracy of a certain brand's value, respondents had to meet the following critical criteria. First, respondents had to have experiences in IRONMAN and other non-IRONMAN triathlon events. It is important to have knowledge of an IRONMAN triathlon event; otherwise, they would have difficulty assigning a dollar value to the research objects. Second, respondents had to have an annual income. An individual's willingness to pay for a focal product is influenced by his or her income level (Castellanos, Garcia, \& Sanchez, 2011; Ryan \& Watson, 2009; Sethuraman \& Cole, 1999). Collectively, there were 349 adult triathletes who knew about and had at least one experience at an IRONMAN and another nonIRONMAN triathlon event and who earned an annual income.

Participants included 129 respondents from the IRONMAN Florida-Full distance event, and 220 respondents participating in the IRONMAN California-Half distance. Considering the consumer price index (CPI) in each cityheld IRONMAN triathlon event, as well as the registration fees, we decided to examine two IRONMAN triathlon events (e.g., California and Florida), which have similar size and cost of living. We estimate whether there is a consistent monetary value that sports consumers perceive toward the brands. In all events, the ratio of males to females was approximately 7:3, and approximately $70 \%$ of participants were in the age range of 30-50. More than $80 \%$ of participants were white, and approximately $70 \%$ had received a bachelor's degree or higher. Half of the participants had a yearly individual income of over $\$ 100,000$. The demographic characteristics between two data sets were very similar $\left(F_{(1,339)}=.26-3.04, p<.05\right)$ and consistent with the general population proportionate to each characteristic.

\subsection{Instrument}

The questionnaire consisted of three sections: (1) past experiences; (2) willingness to pay for triathlon events; and (3) demographic information. The items in the first section were included to assess past experiences with IRONMAN and non-IRONMAN events and reasons for participating in triathlon events. In the second section, two sets of questions were included to measure the respondents' willingness to pay for an IRONMAN-branded event and a non-IRONMAN-branded event.

The items were in open-ended question format such as "How much would you be willing to pay for an IRONMAN event?" and "How much would you be willing to pay for a non-IRONMAN event?" The non-IRONMAN branded event in the current study was a hypothetical event that was presented as having the identical setting and quality as the branded product. The only difference was that the non-IRONMAN triathlon event was not representing the IRONMAN triathlon event.

We applied the CVM to measure brand equity while controlling the biases through particular methodological buffers, including survey methods truth-telling inclusion (e.g., "Please be realistic and honest when reporting your willingness to pay") and detailed explanation of the research object (e.g., "REMEMBER: The Florida Triathlon is NOT an IRONMAN event, but it is the same SETTING and same QUALITY").

\subsection{Data analysis}

The data were first assessed using analysis of variance (ANOVA) to determine if there was any difference between triathletes' willingness to pay for the branded and unbranded research objects. Assumptions for ANOVA included independence, normality, and homogeneity of the variances of the residuals were tested. Descriptive analyses were performed to gather general information. The difference between willingness to pay for the branded IRONMAN triathlon event and non-branded IRONMAN triathlon event was calculated. First, IBM SPSS version 19 was used to analyse the willingness-to-pay amounts and to provide evidence of a price premium. After providing evidence of average willingness-to-pay (i.e., price premium), we estimate an aggregated price premium for the target population. CVM researchers (Atkinson et al., 2008; Humphreys, Johnson, Mason, \& Whitehead, 2011; Johnson, Whitehead, Mason, \& Walker, 2012) have reported average and aggregate willingness-to-pay values from the sample (Abdullah \& Jeanty, 2011; Kallas \& Gil, 2012; Süssmuth, Heyne, \& Maennig, 2010). The aggregated willingness-to-pay value represents the brand equity of the IRONMAN brand in the study because it symbolizes brand equity. Simon and Sullivan (1993) defined brand equity as "the incremental cash flows which accrue to branded products over unbranded products" (p. 28), which is how an average individual evaluates the brand compared with unbranded products in the study. 


\subsection{Results and discussion}

\subsection{Customer's willingness to pay: Brand vs. non-branded events}

A one-way ANOVA was computed to determine if there were any statistical differences between individuals' willingness to pay for the branded and unbranded triathlon events. Willingness to pay for branded and nonbranded events were the between-subjects variables, and event distance-full and half-were the within-subjects variables. Table 3 includes the results from the difference test.

\begin{tabular}{|c|c|c|c|c|c|c|c|c|c|c|c|}
\hline \multicolumn{12}{|c|}{ Table 3: The WTP Difference between IRONMAN and Non-IRONMAN events } \\
\hline & \multicolumn{6}{|c|}{ Distances } & \multirow{2}{*}{\multicolumn{5}{|c|}{$\begin{array}{c}\text { ANOVA: Tests Between-Subjects } \\
\text { Effects }\end{array}$}} \\
\hline \multirow[b]{2}{*}{ WTP } & \multicolumn{2}{|c|}{ Half Distance } & \multicolumn{2}{|c|}{ Full Distance } & \multicolumn{2}{|c|}{ Total } & & & & & \\
\hline & $M$ & $S D$ & $M$ & $S D$ & $M$ & $S D$ & $F$ & $d f 1$ & $d f 2$ & $p$ & $\eta^{2}$ \\
\hline IRONMAN & 382.36 & 164.04 & 727.12 & 240.81 & 510.16 & 257.11 & & & & & \\
\hline $\begin{array}{l}\text { Non- } \\
\text { IRONMAN }\end{array}$ & 262.74 & 135.66 & 394.92 & 189.82 & 311.74 & 170.12 & 144.14 & 1 & 694 & .00 & .17 \\
\hline
\end{tabular}

Note. WTP $=$ Willingness to pay; The WTP Difference $=$ Price premiums.

There was a significant difference in willingness to pay for an IRONMAN event compared with a non-IRONMAN event using a critical $\alpha$ of $.05\left(F_{(1,694)}=144.14, p<.05, \eta^{2}=.17\right)$. Triathletes on average were willing to pay more for the IRONMAN branded events $(\mathrm{M}=510.16, \mathrm{SD}=257.11)$ than the non-IRONMAN events $(\mathrm{M}=311.74, \mathrm{SD}=$ 170.12). The difference, which is evidence of a price premium, constitutes a large effect (e.g., $\eta^{2}>.138$ ) according to Cohen's (1988) guidelines.

For the half-distance events, the average willingness-to-pay figure for the IRONMAN branded event was \$382.36 $(\mathrm{SD}=194.04)$; the average willingness-to-pay figure for the non-IRONMAN event was $\$ 262.74(\mathrm{SD}=135.66)$. The difference between the two figures, \$119.62--the price premium for the IRONMAN Half-distance-was statistically significant: $F_{(1,694)}=209.43, p<.05, \eta^{2}=.17$. The triathletes were willing to pay an additional $\$ 119.62$ for an IRONMAN-brand half-distance triathlon event.

The average willingness-to-pay figure for the full-distance IRONMAN-branded event was \$727.12 (SD = 240.81); the figure for the full-distance non-IRONMAN event was $\$ 394.92$ (SD =189.82). The difference between the two figures, $\$ 332.20$ - the price premium for the IRONMAN full triathlon-was statistically significant: $F_{(1,694)}=$ 209.43, $p<.05, \eta^{2}=.17$. Respondents reported a willingness to pay more for the IRONMAN-branded event. Considering the first hypothesis, there was a difference between a customer's willingness to pay for a branded event compared with a corresponding unbranded event.

The results indicated a statistically significant difference, providing evidence that a price premium did exist. The evidence further supports the existence of the price premium among triathletes for the IRONMAN-brand triathlon events. Overall, triathletes reported significantly higher willingness-to-pay figures for the IRONMAN-branded events than the non-IRONMAN-branded events. The existence of a price premium consumers are willing to pay indicates that the brand has a competitive advantage in the market. Triathletes reported the IRONMAN event was worth investing additional money, even controlling for the quality and setting. What are some implications from these results?

From the organization's perspective, consumers' willingness to pay a price premium indicates the organization has a margin for raising the price that consumers will accept. That is, organizations can raise the price to nearly the average price premium indicated by consumers and generate more profit with identical products. The study results further provide evidence that, regardless of the event's distance, there existed a high price premium among triathletes. If the organization can gain more profit by increasing prices, it can reinvest the money to other marketing planes/mix or research and development for future growth. The reinvestment should foster an additional competitive advantage. That is, the existence of price premiums may provide opportunities for the property to raise the product price, to earn more profits, and to reinvest for further product enhancement. The price premium brings competitive advantage to organizations, which provides positive consequences of branding for property.

\subsection{Aggregate price premium and brand equity}

Researchers who have worked with the CVM report the average willingness-to-pay figure and the aggregate intangible value generated by a sporting event: they estimated the aggregate willingness to pay based on the 
population (see Atkinson et al., 2008; Humphreys, Johnson, Mason, \& Whitehead, 2011; Süssmuth, Heyne, \& Maennig, 2010). We used a similar approach to estimate the brand equity for the IRONMAN brand.

To estimate the equity of the IRONMAN brand, we used the willingness to pay the price premium for each distance (i.e., $\$ 119.62$ for half distance and $\$ 332.2$ for full distance). We multiplied the price premium for each distance by the reported triathlete half-triathlon population and the reported full-triathlon population, respectively. There were a reported 2,184,000 triathletes in 2013 (USA Triathlon Demographics, 2013); half- (39\%) and full-distance (17\%) participation populations were 851,760 and 371,280, respectively. The population figures were multiplied by the respective price premium figures, resulting in a brand equity value of $\$ 101,887,531.20$ (nearly $\$ 102$ million) for half-distance events, and $\$ 123,339,216.00$ (roughly $\$ 123$ million) for full-distance events (see Table 4). Considering the research question, "What is the customer-based brand equity of a sporting event, based on the price premium that an individual places on the brand?" the brand equity of IRONMAN half distance was approximately \$102 million and that of IRONMAN full distance was about \$123 million.

Table 4: Price Premiums and Aggregate Price Premiums (Brand Equity)

\begin{tabular}{lcc} 
& Half Distance & Full Distance \\
\hline Price Premiums & $\$ 119.62$ & $\$ 332.20$ \\
Population (triathletes) & 851,760 & 371,280 \\
Aggregate & $\$ 101,887,531.20$ & $\$ 123.339 .216 .00$ \\
Equity of IRONMAN brand & $\$ 102$ million & $\$ 123$ million \\
\hline
\end{tabular}

Using the CVM, a brand equity value was estimated on the basis of population size and the elicited individual customer's willingness-to-pay figures. This study represents the first effort to provide monetary values of customer-based brand equity. Previously, the economic values of brands were obtained through financial-market measures (Ailawadi et al., 2003; Boone et al., 1995; Dubin, 1998; Feldwick, 1996; Gladden et al., 1998; Mahajan et al., 1994; Simon \& Sullivan, 1993), which are pertinent to a firm's financial statement. One major limitation of the measure was that those data were not derived from actual consumers of the products/brands. When examining customer-based brand equity, previous researchers refer to the existence of brand equity through identifying several components such as brand awareness, brand association, brand loyalty, etc. (Aaker, 1991; Buil, de Chernatony, \& Martinez, 2008; Lassar, Mittal, \& Sharma, 1995; Vázquez, del Rio, \& Iglesias, 2002; Yoo \& Donthu, 2001 Keller, 1993; 2001; Ross, 2006). Discussion of the existence of brand equity in previous research, however, is not the same as actually identifying a specific monetary value for the equity of a specific brand.

An important result from this study was computing brand equity figures based on customers' evaluation of intangible values. An important contribution is demonstrating that the CVM may be used to compute a brand equity value for a participant sports brand based on the consumer's perceptions and evaluations. Being able to compute a specific monetary value provides marketers with several benefits.

First, the value can be a strong selling point for building and developing relationships with business partners. That is, the brand equity value can be advantageous when promoting, advertising, and merchandising or during media negotiations. Instead of a company knowing only that its business partner has brand equity, having an actual dollar value of brand equity would provide a reliable and evident indication for business practitioners and researchers when negotiating business deals.

Second, an actual brand equity value can be an indicator when setting a strategic pricing policy. To estimate the brand equity value, individuals' price premium relative to the branded product was used. As consumers are evidently willing to pay more, managers and executives could realize surplus margins on the basis of the price premium. Loyal customers tend to fluctuate less with price changes; thus, the product price increases may not heavily affect consumers' price perception yet strongly affect gross profits. The current product price and related pricing policy can be monitored and evaluated relative to the brand equity value.

Third, the brand equity value provides information a business may use to examine its current status by comparing its value with competitors' values. Because access to organizational data-including financial data-is restricted in the sports industry, it is difficult to accurately assess competitors' brand equity by using financial market measures. If more information of competitors' brand equity by using the CVM was obtained, practitioners could compare their customer-based brand equity with that of the competitors'. Also, if executors and managers obtain their brand equity value regularly at a certain period of time, they can track the equity of their brand. The customer-based brand equity value can be used as another tool for evaluating and keeping an eye on the health of a brand. To maintain a brand's strength, it is necessary for executives and practitioners to periodically monitor and compare with their competitors. The brand equity value can be used as an indicator of overall performance from the customers' perspectives of a potential change, which can either strengthen or weaken over a period of 
time. The customer-based brand equity value derived by CVM can contribute to the field, especially in those that are not publicly traded corporations (i.e., the organizations that do not release financial information on a regular basis) and those that cannot apply the commercial company's formula for brand value (e.g., Forbes' Most Valuable Sports Brands, Interbrand's Best Brands).

\subsection{Future research direction}

One limitation of this study is accuracy of the brand equity figures. A representative sample derived from a random sampling procedure would allow for an accurate estimation of brand equity. Some CVM researchers have worked with representative sampling techniques and ostensibly reported accurate aggregate willingness-to-pay values (Atkinson et al., 2008; Humphreys, Johnson, Mason, \& Whitehead, 2011; Johnson, Whitehead, Mason, \& Walker, 2012); others have used the CVM without a truly representative sample (Abdullah \& Jeanty, 2011; Kallas \& Gil, 2012; Süssmuth, Heyne, \& Maennig, 2010). Data in the current study were collected through convenience sampling at two triathlon events. In future research, a more accurate measure of brand equity would be computed through the inclusion of a representative sample by probability techniques.

The current study was a first attempt to estimate customer-based brand equity with the CVM. To provide further evidence of validity with the method/technique and results in the context of branding studies, we propose three streams of future research. First, use the CVM to assess brand equity in other participation sports. Despite an increased number of participants in cycling, swimming, fitness and outdoor activities for most adult age groups (PAC 2013 Participation Report, 2013), acknowledging the importance of event brand management seems to be relatively overlooked. For example, although a few nationwide triathlon events (e.g., HITS Triathlon) offer identical distances and characteristics to those of the IRONMAN-branded triathlons, even fewer brands seem to stand out. As a result, the participation of sport-related brands are rarely examined/ranked in practice or as subjects of academic research. The CVM approach enables researchers to assess the equity of all sorts of serviceoriented brands, whether notable and powerful or local brands. Thus, attaining more evidence on brand value of participation sports would be meaningful and helpful in strengthening the case of validity, advance our understanding of participation sport brand equity, and provide potential application to other sporting events.

Second, comparing the value derived from using CVM with Forbes' estimation would provide further evidence of the validity of the results. Forbes annually reports on the 10 most valuable sports brands in each of four categories: business, events, teams, and athletes. Brand values are based on the organizational data obtained from financial reports and several other resources, which indicate that these values are not based on the consumers' perspectives and evaluations. The figures from the CVM provide a customer-based brand equity value. Thus, comparing the customer-based brand equity figure with the Forbes' firm-based valuation could provide some indication of external validity.

Third, tracking the longitudinal trend of brand equity of sports products, thus tracing the brand equity of identical sports products, would help managers to plan marketing strategies. Following the trend of a product's brand value over time may indicate how well the execution of multiple planning and strategies (e.g., marketing tactics and organizational managements) have worked in the marketplaces and whether the brand equity changes over time. Tracking brand equity, as well as significant determinants influencing equity, would benefit marketers by providing information they may use to build strong brand equity and broaden the understanding of customerbased brand equity measures.

\subsection{Conclusion and policy implications}

The purpose of the study was to assess brand equity from a sport consumer's perspective through use of the CVM. Two research questions were posed to capture the intangible benefits that customers perceived from recognizing the brand. The Price premiums that individual triathletes were willing to pay were present and the dollar value of brand equity was estimated based on the Price premium. The primary significance of the study is that this is a first attempt to estimate customer-based brand equity with the CVM in the service-oriented product context.

The dollar value inferred through willingness to pay for the Price premium utilizing the CVM offers several potential benefits. First, the value can be a strong selling point for building and developing relationships with business partners instead of simply claiming that their company has brand equity; revealing research of a specific brand equity value provides a confident and strong selling point. Second, an actual brand equity value can be an indicator when setting a strategic pricing policy: loyal customers (i.e., one of indicators of a high level of brand equity) tend to be less vulnerable to fluctuating prices; managers can consider increasing their product prices based on the brand equity value. Third, numerically describing a brand value enables practitioners to examine their current status by comparing the value with competitors, to trace their own brand equity from time to time 
and identify potential issues using the value as an indicator. The actual dollar value can provide meaningful insight to practitioners and researchers. Future research is suggested to provide evidence of method and result validity because the study presents initial evidence of brand equity figures. It is hoped that the current study established an important initial step to advance our understanding of brand equity and its measurement in the context of sport.

\section{References}

Aaker, D.A. (1991), Managing Brand Equity. The Free Press: New York, NY.

Aaker, D. A. (1996). Measuring brand equity across products and markets. California Management Review, 38, 102-120. http://dx.doi.org/10.2307/41165845

Abdullah, S., \& Jeanty, P. W. (2011). Willingness to pay for renewable energy: Evidence from a contingent valuation survey in Kenya. Renewable and Sustainable Energy Reviews, 15(6), 2974-2983. http://dx.doi.org/10.1016/j.rser.2011.03.016

Agarwal, M. \& Rao. V. (1996). An empirical comparison of consumer-based measures of brand equity. Marketing Letters, 7, 237-47. http://dx.doi.org/10.1007/BF00435740

Ailawadi, K. L., Lehmann, D. R., \& Neslin, S. A. (2003). Revenue premium as an outcome measure of brand equity. Journal of Marketing, 67, 1-17. http://dx.doi.org/10.1509/jmkg.67.4.1.18688

Ambler, T. (2003). Marketing and the Bottom Line: The Marketing Metrics that Will Pump Up Cash Flow. Pearson Education.

Anselmsson, J., Johansson, I., \& Persson, N. (2007). Understanding Price Premium for grocery products: a conceptual model of customer-based brand equity. Journal of Product \& Brand Management, 16, 401-414. http://dx.doi.org/10.1108/10610420710823762

Arrow, K., Solow, R., Portney, P. R., Leamer, E. E., Radner, R., \& Schuman, H. (1993), Report of the NOAA Panel on Contingent Valuation. Federal Register, 58, 4601-4614.

Atkinson, G., Mourato, S., Szymanski, S., \& Ozdemiroglu, E. (2008). Are We Willing to Pay Enough to Back the Bid?: Valuing the Intangible Impacts of London's Bid to Host the 2012 Summer Olympic Games. Urban Studies, 45, 419-444.

Blomquist, G. C., \& Whitehead, J. C. (1998). Resource quality information and validity of willingness to pay in contingent valuation. Resource and Energy Economics, 20(2), 179-196. http://dx.doi.org/10.1016/S09287655(97)00035-3

Boone, L.E., Kochunny, C.M., \& Wilkins, D. (1995). Applying the brand equity concept to Major League Baseball. Sport Marketing Quarterly, 4, 33-42.

Buil, I., de Chernatony, L., \& Martinez, E. (2008). A cross-national validation of the consumer-based brand equity scale. Journal of Product and Brand Management, 17, 384-392. http://dx.doi.org/10.1108/10610420810904121

Carson, R. T., \& Mitchell, R. C. (1993). The value of clean water: The public's willingness to pay for boatable, fishable, and swimmable quality water. Water Resources Research, 29, 2445-2454. http://dx.doi.org/10.1029/93WR00495

Castellanos, P., Garcia, J. \& Sanchez, J. M. (2011). The willingness to pay to keep a football club in a city: How important are the methodological issues? Journal of Sports Economics, 12, 464-486. http://dx.doi.org/10.1177/1527002510385301

Coates, D., \& Humphreys, B. R. (1999). The growth effects of sport franchises, stadia, and arenas. Journal of Policy Analysis and Management, 18, 601-624. http://dx.doi.org/10.1002/(SICI)15206688(199923)18:4<601::AID-PAM4>3.0.C0;2-A

Coates, D., \& Humphreys, B. R. (2000). Stadium gambit and local economic development. The Regulation, 23, 15.

Cohen, J. (1988). Statistical power analysis for the behavioral sciences. Psychology Press.

Courey, A. (2013, July 30). The growing triathlon industry. Xpress economy. Retrieved from http://www.tremblantexpress.com/the-growing-triathlon-industry.html.

Crompton, J. L. (1995). Economic impact analysis of sports facilities and events: Eleven sources of misapplication. Journal of Sport Management, 9, 14-35.

Crompton, J. (2004). Beyond economic impact: An alternative rationale for the public subsidy of major league sports facilities. Journal of Sport Management, 18, 40-58.

Cummings, R. G., Brookshire, D. S., Schulze, W. D., Bishop, R. C., \& Arrow, K. J. (1986). Valuing environmental goods: an assessment of the contingent valuation method. Totowa, NJ: Rowman \& Allanheld.

de Chernatony, L., Harris, F., \& Christodoulides, G (2004). Developing a brand performance measure for financial

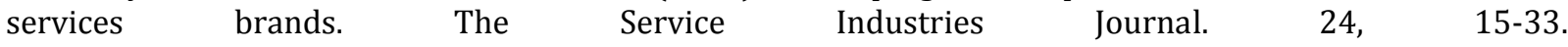
http://dx.doi.org/10.1080/02642060412331301232

Drayer, J., \& Shapiro, S. L. (2011). An examination into the factors that influence consumers' perceptions of value. Sport Management Review, 14, 389-398. http://dx.doi.org/10.1016/j.smr.2010.11.001 
Dubin, J. A. (1998). The demand for branded and unbranded products: An econometric method for valuing intangible assets. Chapter 4 in Studies in consumer Demand: Econometric methods applied to market data. Norwell, MA:Kluwer Academic publishers, 77-127. http://dx.doi.org/10.1007/978-1-4615-5665-7_4

Faircloth, J. B., Capella, L. M., \& Alford, B. L. (2001). The effect of brand attitude and brand image on brand equity. Journal of Marketing Theory and Practice, 9, 61-75.

Farquhar, P.H. (1989). Managing brand equity. Marketing Research, 1, 24-33.

Farquhar, P.H. (1990). Managing brand equity. Journal of Advertising Research, 30, RC7-11.

Feldwick, P. (1996). What is brand equity anyway, and how do you measure it? Journal of the Market Research Society, 38, 85-104.

Gladden, J., Irwin, R., \& Sutton, W. (2001). Managing North American major professional sport teams in the new millennium: A focus on building brand equity. Journal of Sport Management, 15, 297-317.

Gladden, J., Milne, G., \& Sutton, W. (1998). A conceptual framework for evaluating brand equity in Division I college athletics. Journal of Sport Management, 12, 1-19.

Gladden, J. M., \& Milne, G. R. (1999). Examining the importance of brand equity in professional sports. Sport Marketing Quarterly, 8, 21-30.

Holbrook, M. B. (1992). Product quality, attributes, and brand name as determinants of price: The case of consumer electronics. Marketing Letters, 3, 71-83. http://dx.doi.org/10.1007/BF00994082

Humphreys, B. R., Johnson, B. K., Mason, D. S., \& Whitehead, J. (2011). Estimating the value of medal success at the 2010 Winter Olympic Games (No. 11-20).

Johnson, B. K., Groothuis, P. A., \& Whitehead, J. C. (2001). The Value of Public Goods Generated by a Major League Sports Team The CVM Approach. Journal of Sports Economics, 2, 6-21. http://dx.doi.org/10.1177/152700250100200102

Johnson, B., Mondello, M., \& Whitehead, J. C. (2007). The value of public goods generated by a National Football League team. Journal of Sport Management, 21, 123-136.

Johnson, B. K., \& Whitehead, J. C. (2000). The value of public goods from sport stadiums: the CVM approach. Contemporary Economic Policy, 18, 48-58. http://dx.doi.org/10.1111/j.1465-7287.2000.tb00005.x

Johnson, B. K., Whitehead, J. C., Mason, D. S., \& Walker, G. J. (2007). Willingness to pay for amateur sport and recreation programs. Contemporary Economic Policy, 25, 553-564. http://dx.doi.org/10.1111/j.14657287.2007.00072.x

Johnson, B. K., Whitehead, J. C., Mason, D. S., \& Walker, G. J. (2012). Willingness to pay for downtown public goods generated by large, sports-anchored development projects: The CVM approach. City, Culture and Society, 3(3), 201-208. http://dx.doi.org/10.1016/j.ccs.2012.06.007

Kallas, Z., \& Gil, J. M. (2012). Combining contingent valuation with the analytical hierarchy process to decompose the value of rabbit meat. Food Quality and Preference, 24(2), 251-259. http://dx.doi.org/10.1016/j.foodqual.2011.11.006

Kapferer, J. N. (2004). The New Strategic Brand Management. Kogan Page: London.

Keller, K.L. (1993). Conceptualizing, measuring and managing customer-based brand equity. Journal of Marketing, 57, 1-22. http://dx.doi.org/10.2307/1252054

Keller, K. L. (2001). Building customer-based brand equity. Marketing Management, July/August, 15-19.

Keller, K. L. (2008). Strategic Brand Management. Building, Measuring, and Managing Brand Equity. Upper Saddle River, NJ: Pearson Prentice Hall.

Keller, K. L., \& Lehmann, D. R. (2006). Brands and branding: Research findings and future priorities. Marketing Science, 25, 740-759. http://dx.doi.org/10.1287/mksc.1050.0153

Klose, T. (1999). The contingent valuation method in health care. Health Policy, 47, 97-123. http://dx.doi.org/10.1016/S0168-8510(99)00010-X

Krishnan, B. C., \& Hartline, M. D. (2001). Brand equity: Is it more important in services?. Journal of Services Marketing, 15, 328-342. http://dx.doi.org/10.1108/EUM0000000005654

Lassar, W., Mittal, B., \& Sharma, A. (1995). Measuring customer-based brand equity. Journal of Consumer Marketing, 12, 11-19. http://dx.doi.org/10.1108/07363769510095270

Mahajan, V., Rao, V. R., \& Srivastava, R. K. (1994). An approach to assess the importance of brand equity in acquisition decisions. Journal of Product Innovation Management, 11, 221-235. http://dx.doi.org/10.1111/1540-5885.1130221

Mackay, M. M. (2001) Evaluation of brand equity measures: Further empirical results. Journal of Product \& Brand Management, 10, 38-51. http://dx.doi.org/10.1108/10610420110382812

Netemeyer, R. G., Krishnan, B., Pullig, C., Wang, G., Yagci, M., Dean, D., Ricks, J., \& Wirth, F. (2004). Developing and validating measures of facets of customer-based brand equity. Journal of Business Research, 57, $209-224$. http://dx.doi.org/10.1016/S0148-2963(01)00303-4

PAC $2013 \quad$ Participation $\quad$ Report $\quad$ (2013). Retrieved from http://www.physicalactivitycouncil.com/PDFs/2013_PAC_Overview_Report_Final.pdf

Park, C. S., \& Srinivasan, V. (1994). A survey-based method for measuring and understanding brand equity and its extendibility. Journal of Marketing Research, 31, 271-288. http://dx.doi.org/10.2307/3152199 
Peterson, R. A., \& Wilson, W. R. (1985). Perceived risk and price-reliance schema as price-perceived quality mediators. Perceived Quality, 247-68.

Rätzel, S., \& Weimann, J. (2006). Der Maradona Effekt: Wie viel Wohlfahrt schafft die deutsche Nationalmannschaft? Perspektiven der Wirtschaftspolitik, 7(2), 257-270. http://dx.doi.org/10.1111/j.14656493.2006.00208.x

Rollins, K. \& Wistowsky, W. (1997). Benefits of back-country canoeing in Ontario wilderness parks. Journal of Applied Recreation Research, 221, 9-31.

Ross, S. D. (2006). A conceptual framework for understanding spectator-based brand equity. Journal of Sport Management, 20, 22-38.

Rulleau, B., Dehez, J., \& Point, P. (2012). Recreational value, site characteristics and user heterogeneity in contingent valuation. Tourism Management, 33, 195-204. http://dx.doi.org/10.1016/j.tourman.2011.03.002

Ryan, M., \& Watson, V. (2009). Comparing welfare estimates from payment card contingent valuation and discrete choice experiments. Health Economics, 18, 389-401. http://dx.doi.org/10.1002/hec.1364

Sethuraman, R. (2001). What makes consumers pay more for national brands than for store brands-image or quality?. Review of Marketing Science, 318, 1-37.

Sethuraman, R., \& Cole, C. (1999). Factors influencing the Price Premiums that consumers pay for national brands over store brands. Journal of Product \& Brand Management, 8, 340-351. http://dx.doi.org/10.1108/10610429910284319

Shapiro, C. (1983). Premiums for high quality products as returns to reputations. Quarterly Journal of Economics, 98, 659-679. http://dx.doi.org/10.2307/1881782

Shyamsundar, P., \& Kramer, R. A. (1996). Tropical forest protection: An empirical analysis of the costs borne by local people. Journal of Environmental Economics and Management, 31, 129-144. http://dx.doi.org/10.1006/jeem.1996.0036

Simon, C. J., \& Sullivan, M. V. (1993). The measurement of determinants of brand equity: A financial approach. Marketing Science, 12, 28-52. http://dx.doi.org/10.1287/mksc.12.1.28

Süssmuth, B., Heyne, M., \& Maennig, W. (2010). Induced Civic Pride and Integration. Oxford Bulletin of Economics and Statistics, 72, 202-220. http://dx.doi.org/10.1111/j.1468-0084.2009.00575.x

U.S.A. Triathlon Demographics (2013). Retrieved from http://www.usatriathlon.org/aboutmultisport/demographics.aspx

Vázquez, R. K., del Rio, A. B., \& Iglesias, V. (2002). Consumer-based brand equity: Development and validation of a measurement instrument. Journal of Marketing Management, 18, 27-48. http://dx.doi.org/10.1362/0267257022775882

Walker, M., \& Mondello, M. J. (2007). Moving beyond economic impact: A closer look at the contingent valuation method. International Journal of Sport Finance, 2(3), 149-160.

Walton, H., Longo, A. \& Dawson, P. A. (2008) Contingent valuation of the 2012 London Olympic Games: A regional perspective. Journal of Sports Economics, 9, 304-317. http://dx.doi.org/10.1177/1527002507308769

Whitehead, J. C., \& Cherry, T. L. (2007). Willingness to pay for a green energy program: A comparison of ex-ante and ex-post hypothetical bias mitigation approaches. Resource and Energy Economics, 29, $247-261$. http://dx.doi.org/10.1016/j.reseneeco.2006.10.001

Wicker, P. (2011). Willingness-to-pay in non-profit sports clubs. International Journal of Sport Finance, 6, 155169.

Wicker, P., Prinz, J., \& von Hanau, T. (2012). Estimating the value of national sporting success. Sport Management Review, 15, 200-210. http://dx.doi.org/10.1016/j.smr.2011.08.007

Yoo, B., \& Donthu, N. (2001). Developing and validating a multidimensional consumer-based brand equity scale. Journal of Business Research, 52, 1-14. http://dx.doi.org/10.1016/S0148-2963(99)00098-3 